\title{
THERMOPERIODITY AND FLOWER FORMATION IN SOME TOMATO VARIETIES
}

\author{
LEA M. KURKI \\ Department of Horticulture, University of Helsinki \\ and \\ S. H. WitTwer
}

Department of Horticulture, Michigan State University, East Lansing, Michigan, USA

Received June 20, 1956

The term thermoperiodicity, suggested and defined by Went (16), is used for all responses of plants, whether they be flowering, fruiting or growth, to cyclic temperature variations. CHOUARD (2) has divided these responses into annual and diurnal thermoperiodicity. The former is found in deciduous trees, shrubs and most plants with underground storage organs in which development occurs only when periods of high temperature alternate with periods of low temperature. An example of annual thermoperiodicity is the development of the tulip hyacinth and many other bulbs. BLAauw (4) and collaborators have shown that each developmental process in bulbous plants has its own optimal temperature.

The concept of diurnal thermoperiodicity includes the responses of plants to the daily cycle of higher day and lower night temperatures. These responses have been studied in the greatest detail in the tomato plant by Went $(15,16,17)$. He has shown that in the tomato plant each phase of development has its own optimal temperature, and according to him the optimal range for fruit setting is: day temperature approximately $77^{\circ} \mathrm{F}$, night temperature $59-68^{\circ} \mathrm{F}$. The optimum night temperature varies slightly with varieties. In addition WENT (17) has reported that the optimal night temperature increases with illuminating during the light period.

With respect to flower formation, the sensitive period for the temperature effect on the first inflorescence has been shown by Lewis (11) to be between the 8th and 12 th day after cotyledon expansion. According to LAWREnce (7) this period is 
between the 8 th and 18 th day after cotyledon expansion at $60^{\circ} \mathrm{F}$, and, if the temperature falls to $54^{\circ} \mathrm{F}$, the sensitive period is between the 15 th and 21 st day.

Night temperatures during the early stage of growth not only affect flower number, but also affect the position on the stem at which the first inflorescence will develop $(8,13,14,19)$. That the period of low temperatures also retards the rate of growth is natural, and prolonged exposure to low night temperatures results in poor fruit setting and misshapen fruits as reported by LAWRENCE (7) among others.

The cultivated tomato is classified as a day neutral plant. However, the structure of tomato flower, especially the development of male gametophyte seems to be influenced by the length of day $(1,5,6,10,11)$. The day length, whether 8 or 16 hours does not influence the position of the first inflorescence (9).

In order to study further the thermoperiodic responses of different tomato varieties, an experiment was designed in which twelve tomato varieties were exposed to low $\left(50\right.$ to $\left.55^{\circ} \mathrm{F}\right)$ and high $\left(65\right.$ to $\left.70^{\circ} \mathrm{F}\right)$ night temperatures. The experiment was carried out in temperature-controlled greenhouses at Michigan State University, U.S.A.

Seeds were sown in flats of vermiculite February 18, 1955. The temperature during the germination phase was $75-80^{\circ} \mathrm{F}$. Seedlings were transplanted February 25. to $4^{\prime \prime}$ clay pots of steam sterilized sandy loam. There were ten replications of each variety at each of two temperatures consisting of a single plant. During the temperature sensitive period for flower formation in the first cluster two night temperatures were utilized the one consisting of $50-55^{\circ} \mathrm{F}$, and the other of $65-$ $70^{\circ} \mathrm{F}$. Day temperatures were about $77^{\circ} \mathrm{F}$. The time of exposure lasted for two weeks, beginning March 2, at the time when the plumule leaves were just beginning to show, and the cotyledons were fully expanded. After the temperature treatment the plants were transferred to $6^{\prime \prime}$ clay pots, and returned to about $65^{\circ} \mathrm{F}$ night temperature. The plants were fertilized with "Take Hold»-solution every 7 to 10 days, beginning just after germination. The analysis of Take Hold fertilizer is $\mathrm{N}=10 \%, \mathrm{P}_{2} \mathrm{O}_{5}=52 \%$, and $\mathrm{K}_{2} \mathrm{O}=17 \%$. The rate of application was one ounce to a gallon of water.

The results of the experiment are recorded in Tables 1 and 2. The rate of development was retarded by low night temperature in every variety except Rutgers The number of nodes to the first flower cluster was decreased by low night temperature in all cases, and even the number of nodes to the second cluster in most varieties (Table 1).

The size of the first and second inflorescence was in general increased when the night temperature was low at the time of flower differentiation. The varieties. J. Moran and Pearson, adapted to conditions prevailing in the western parts of the United States, responded, however, negatively to $50-55^{\circ} \mathrm{F}$ night temperatures (Table 2). The number of nodes and therefore also the number of leaves to the first inflorescence was decreased by low night temperature, but the number of days to the first open flower was increased.

The results of the experiment prensented above agree with those already found in the literature. It remains to be seen whether the period of two weeks cold exposure 
Table 1. Effect of night temperature on days to first open flower, and number of nodes to first and second flower cluster.

Taulu 1. Yölämpötilan vaikutus päivien lukumäärään laskettuna kylvöstä ensimmäiseen avautuneeseen kukkaan sekä nivelien lukumäärään ennen ensimmäistä ja toista kukintoa.

\begin{tabular}{|c|c|c|c|c|c|c|}
\hline \multicolumn{2}{|c|}{ Night temperature - Yölämpötila } & \multicolumn{2}{|c|}{$50-55^{\circ} \mathrm{F}$} & \multicolumn{2}{|c|}{$65-70^{\circ} \mathrm{F}$} & \multirow[b]{2}{*}{$\begin{array}{l}\text { No. of nodes } \\
\text { to second } \\
\text { cluster } \\
\text { Nivelien luku } \\
\text { toiseen tert- } \\
\text { tuun }\end{array}$} \\
\hline $\begin{array}{l}\text { Variety } \\
\text { Lajike }\end{array}$ & $\begin{array}{l}\text { Days to first } \\
\text { open flower } \\
\text { Päiviä ensim. } \\
\text { avaut. kuk- } \\
\text { kaan }\end{array}$ & $\begin{array}{l}\text { No. of nodes } \\
\text { to first open } \\
\text { cluster } \\
\text { Nivelien luku } \\
\text { ensim. tert- } \\
\text { tuun }\end{array}$ & $\begin{array}{l}\text { No. of nodes } \\
\text { to second } \\
\text { cluster } \\
\text { Nivelien luk } \\
\text { toiseen tert- } \\
\text { tuun }\end{array}$ & $\begin{array}{l}\text { Days to first } \\
\text { open flower } \\
\text { Päiviä ensim. } \\
\text { avaut. kuk- } \\
\text { kaan }\end{array}$ & $\begin{array}{l}\text { No. of nodes } \\
\text { to first } \\
\text { cluster } \\
\text { Nivelien luku } \\
\text { ensim. tert- } \\
\text { tuun }\end{array}$ & \\
\hline Early Chatham & 57 & 4.7 & 5.9 & 54 & 5.4 & 6.0 \\
\hline Early Wonder & 59 & 4.9 & 6.3 & 56 & 5.6 & 7.0 \\
\hline Potentate & 63 & 6.0 & 9.9 & 60 & 6.0 & 9.4 \\
\hline Waltham Forcing & 62 & 5.4 & 8.6 & 52 & 5.6 & 8.3 \\
\hline Manalucie & 61 & 5.9 & 9.3 & 54 & 6.3 & 9.2 \\
\hline Rutgers & 65 & 6.7 & 9.9 & 66 & 6.8 & 9.9 \\
\hline Urbana & 59 & 5.4 & 7.2 & 57 & 6.1 & 7.2 \\
\hline Early Hycross & 58 & 5.3 & 8.4 & 54 & 6.0 & 8.7 \\
\hline J. Moram & 63 & 6.2 & 8.9 & 59 & 7.1 & 10.0 \\
\hline Pearson & 65 & 5.9 & 8.3 & 60 & 7.4 & 9.5 \\
\hline Mich. Ohio Hybrid & 60 & 5.7 & 9.1 & 56 & 7.0 & 10.0 \\
\hline Ohio WR Globe & 59 & 5.8 & 9.1 & 55 & 6.5 & 9.4 \\
\hline
\end{tabular}

Table 2. Effect of low and high night temperature at the early stage of growth on the number of flower in the first and second flower cluster.

Taulu 2. Varhaisen kehitysvaiheen aikana vallinneen matalan ja korkean yölämpötilan vaikutus kukkien lukumäärään ensimmäisessä ja toisessa tertussa.

\begin{tabular}{|c|c|c|c|c|}
\hline \multicolumn{2}{|c|}{ Night temperature - Yölämpötila } & \multirow{2}{*}{$\begin{array}{c}50-55^{\circ} \mathrm{F} \\
\text { No. of flowers in } \\
\text { second cluster } \\
\text { Kukkien lukumäärä } \\
\text { toisessa tertussa }\end{array}$} & \multicolumn{2}{|c|}{$65-70^{\circ} \mathrm{F}$} \\
\hline $\begin{array}{l}\text { Variety } \\
\text { Lajike }\end{array}$ & $\begin{array}{c}\text { No. of flowers in } \\
\text { first cluster } \\
\text { Kukkien lukumäärä } \\
\text { ensim. tertussa }\end{array}$ & & $\begin{array}{l}\text { No. of flowers in } \\
\text { first cluster } \\
\text { Kukkien lukumäärä } \\
\text { ensim. teriussa }\end{array}$ & $\begin{array}{l}\text { No. of flowers in } \\
\text { second cluster } \\
\text { Kukkien lukumäärä } \\
\text { toisessa tertussa }\end{array}$ \\
\hline Early Chatham & 14.3 & - & 12.6 & - \\
\hline Early Wonder & 12.5 & - & 11.3 & - \\
\hline Potentate & 8.4 & 7.2 & 6.4 & 7.4 \\
\hline Waltham Forcing & 6.8 & 7.5 & 7.1 & 7.2 \\
\hline Manalucie & 5.8 & 6.2 & 5.2 & 5.8 \\
\hline Rutgers & 6.7 & 6.9 & 5.9 & 6.4 \\
\hline Urbana & 6.8 & 5.7 & 5.3 & 5.5 \\
\hline Early Hycross & 7.5 & 6.8 & 6.1 & 6.1 \\
\hline J. Moran & 4.8 & 4.9 & 5.1 & 5.5 \\
\hline Pearson & 5.2 & 5.4 & 7.4 & 6.1 \\
\hline Mich. Ohio Hybrid & 6.8 & 7.8 & 6.0 & 6.1 \\
\hline Ohio WR Slobe & 6.3 & 6.5 & 6.0 & 6.3 \\
\hline
\end{tabular}


is optimal for the temperature effect on the first and second flower cluster, and whether the of low ( 50 to $55^{\circ} \mathrm{F}$ ) temperature can be nullified e.g. by high temperature after cold treatment.

The understanding of the process occurring within the plant when exposed to a low night temperature at an early stage of growth, and resulting in changes in number of leaves and in number of flowers, is far from complete. It is known, for instance, that the amount of sugar translocated in the tomato plant, increases as the temperature decreases (18), but little is known as to what this increased sugar translocation has to do with the differentiation of the floral meristem.

According to Crane (3) the simple type of inflorescence in tomato is due to a completely dominant gene. Lewis (8) has found that this dominance can be changed by the environment. An interesting result of LEwIs's (12) work with the gene cytoplasmic interaction is the production of an $\mathrm{F}_{1}$-hybrid tomato, which has the ability to develop flowers and fruits during the early winter months when the flowering and fruiting of tomato varieties and hybrids in general is poor or absent.

\section{Sum $m$ ary}

Twelve tomato varieties were exposed to night temperatures of $50-55^{\circ} \mathrm{F}$ and $65-70^{\circ} \mathrm{F}$ for two weeks just after cotyledon expansion beginning one week after the seed was sown. The responses of each variety were observed as regards the days to the first open flower, the number of leaves formed before the first inflorescence, and the number of flowers in the first and second inflorescence.

A night temperature of $50-55^{\circ} \mathrm{F}$ increased the number of days to the first open flower, and decreased the number of leaves.

The number of flowers in the first inflorescence was increased in all varieties except. J. Moran and Pearson by night temperatures of $50-55^{\circ} \mathrm{F}$.

\section{REFERENCES}

(1) Burk, E. F. 1930. The role of pistil length in the development of forcing tomatoes. Proc. Amer. Soc. Hort. Sci. 26: $239-240$.

(2) Chouard, P. 1951. Cours Cond. Nat. et Metiers (Centre de Documentation Universitaire) Paris. 157 p. Quoted from Went, F. W. Ann. Rev. Pl. Physiol. 4: 347-362.

(3) Crane, M. B. 1915. Heredity of types of inflorescence and fruits in tomato. J. Genet. 5: 1-11.

(4) Hartsema, A. M., Luyten, I. \& Blanuw, A. H. 1930. Verh. Kon. Akad. Wetensh. Amsterdam 27: 146. Quoted from Murneek, A. E. and Whyte, R. O. 1948. Vernalization and photoperiodism. A Sympiosum. $147-157 \mathrm{p}$.

(5) Howlett, F. S. 1936. The effect of carbohydrate and nitrogen deficiency upon microsporagensis and the development of the male gametophyte in the tomato (Lycopersicum esculentum). Ann. Bot. 50: $767-803$.

(6) - $\rightarrow$ 1939. The modification of flower structure by environment in varieties of Lycopersicum esculentum. J. Agric. Res. 58: 79-117. 
(7) Lawrence, W. J. C. 1952. Methods of raising. plants John Innes Hort. Inst. 43rd Ann. Rep.: 26.

(8) - - 1953. Temperature and tomato flowering. Ibid. 44th Ann. Rep.: $23-24$.

(9) — - 1954. Temperature and tomato flowering. Ibid. 45th Ann. Rep.: 26.

(10) Lewis, D. 1949. Temperature and fertility. Ibid. 40th Ann. Rep.: 13.

(11) — 1953. Some factors affecting flower production in the tomato. J. Hort. Sci. $23: 217-220$.

(12) —- 1954. Gene cytoplasmic interaction. John Innes Hort. Inst. 45th Ann. Rep.: 13 - 14.

(13) Reinders-gouwentak, C. A. 1954. Growth and flowering in artificial light. II - Flower initiation. Proc. K. Nederl. Akad. v. Wetensch. Series C, 57: 594-600.

(14) Roodenburg, J. W. M. 1952. Environmental factors in greenhouse culture. Rep. 13th, Intern. Hort. Congr.: 117-126.

(15) Went, F. W. 1944. Plant growth under conrolled conditions II. Amer. J. Bot. 31: $135-150$.

(16) - - $1944 \mathrm{a}$. Plant growth under controlled conditions III. Ibid. 31: 597-618.

(17) — - 1945. Plant growth under controlled conditions V. Ibid. 32: $469-479$.

(18) - 1949. The effect of temperature upon translocation of carbohydrates in the tomato plant. Pl. Physiol. 24: 505-526.

(19) Verkerk, K. 1955. Temperature light and the tomato. Diss. Hortic. Lab. Agric. Univ. Wageningen, Netherlands.

SEL OST US:

TERMOPERIODISMI JA KUKKIEN MUODOSTUMINEN ERÄILLÄ TOMAATTI-

LA JIKKEILLA

LEA M. KURKI

Helsingin yliopiston puutarhatieteen laitos

ja

S. H. WitTWER

Michiganin valtion yliopiston puutarhatieteen laitos, East Lansing, Michigan, USA.

Jaksottaisella lämpötilavaihtelulla on todettu olevan vaikutusta kasvien kehitykseen: kasvuun, kukintaan tai hedelmien muodostumiseen. Jaksojen pituuden perusteella eroitetaan vuotuinen ja vuorokautinen lämpöjaksollisuus toisistaan. Esimerkkinä edellisestä mainitaan lehtipuut ja pensaat sekä sipulikasvit. Vuorokautinen lämpöjaksollisuus käsittää vuorokauden valoisan ajan, päivän, sekä pimeän ajan, yön lämpötilojen vaikutusta kasviin. Ilmiötä on tutkittu yksityiskohtaisesti tomaatilla. On todettu tomaatin jokaisella kehitysvaiheella olevan oma optimaalinen lämpötilansa, joka kuitenkin vaihtelee lajikkeesta ja päivän valonvoimakkuudesta riippuen.

Yölämpötilan vaikutus tomaatin kehitykseen ilmenee esimerkiksi siinä, mihin kohtaan versossa ensimmäinen kukkaterttu muodostuu, sekä siinä, miten suureksi kukkien lukumäärä tertussa nousee. Se kehitysaste, jona yölämpötilalla voidaan vaikuttaa tomaatin ensimmäisen kukinnon asemaan ja kukkien lukumäärään kukinnossa, alkaa useiden tutkijoiden mukaan kahdeksantena vuorokautena sirkkalehtien puhkeamisesta ja kestää 8-18 vuorokautta, jos yölämpötila on $+15^{\circ} \mathrm{C}\left(60^{\circ} \mathrm{F}\right)$.

Michiganin valtion yliopistossa, suoritetuissa kokeissa oli tarkasteltu alhaisen $\left(50-55^{\circ} \mathrm{F}\right.$ eli $\left.10-13.5^{\circ} \mathrm{C}\right)$ ja korkean $\left(65-70^{\circ} \mathrm{F}\right.$ eli $\left.18-21^{\circ} \mathrm{C}\right)$ yölämpötilan vaikutusta ensimmäisen kukinnon asemaan versossa sekä kukkien lukumäärään kahdessa ensimmäisessä kukinnossa 12:1la tomaattilajikkeella. Lämpötilakäsittely alkoi viikon kuluttua kylvämisestä eli ajankohtana, jolloin sirkkalehdet olivat täysin puhjenneet ja alkiosilmu alkoi juuri näkyä, kestäen kaksi viikkoa. Päivälämpötila oli käsittelyn aikana noin $+25^{\circ} \mathrm{C}\left(77^{\circ} \mathrm{F}\right)$. 
Koetulokset osoittavat, että alhainen yölämpötila $10-13.5^{\circ} \mathrm{C}\left(50-55^{\circ} \mathrm{F}\right)$ myöhästytti kaikkien lajikkeiden kukkien avautumista ja vähensi ennen ensimmäistä kukkaterttua muodostuneiden lehtien lukumäärää (taul. 1). Saman lämpötilan vaikutuksesta lisääntyi kukkien lukumäärä ensimmäisessä ja toisessa tertussa muissa lajikkeissa paitsi J. Moran'issa ja Pearson'issa (taul. 2). Kahden viimeksi mainitun tomaattilajikkeen suhtautuminen kokeessa käytettyihin yölämpötiloihin osoittaa, että eri lajikkeilla on eroavaisuuksia suhtautumisessaan yölämpötilaan. 